\title{
PENGARUH KULIAH DARING SAAT PANDEMI COVID-19 TERHADAP KEMAMPUAN MAHASISWA
}

\author{
Aprilia Harapani \\ Program Studi Psikologi Fakultas Kedokteran Universitas Lambung Mangkurat \\ E-mail : apriliaharapanilia@gmail.com
}

\begin{abstract}
Currently the world is faced with the covid-19 pandemic, including Indonesia. The covid-19 pandemic has stopped almost all activities, including the world education, which is forced to learn online or daring, especially in universities to reduce the spread of covid-19 in Indonesia. Online lectures have an impact on students 'abilities, and the purpose of this paper is to find out how online lectures impact students' abilities. The method used is the literature study method, namely the activity of looking for references related to reading, taking notes, collecting data and processing research materials from journals, books, articles, and the internet. It can be concluded thelat online lectures have an impact on students' abilities either decreasing or increasing back to how the learning system is applied to oneself.
\end{abstract}

Keywords : covid-19, online lecture, student abilities

\begin{abstract}
Abstrak
Saat ini dunia sedang dihadapkan dengan pandemi covid-19 tidak terkecuali negara Indonesia. Pandemi covid-19 membuat hampir seluruh kegiatan dihentikan sementara waktu termasuk dunia pendidikan yang terpaksa melaksanakan pembelajaran secara online atau daring khususnya di perguruan tinggi, langkah ini dilakukan untuk mengurangi penyebaran covid-19 di Indonesia. Kuliah daring memiliki berbagai berdampak pada kemampuan mahasiawa. Tujuan dari penulisan ini untuk mengetahui bagaimana dampak kuliah daring terhadap kemampuan mahasiswa. Metode yang digunakan adalah metode studi literatur yaitu kegiatan mencari referensi yang berhubungan dengan metode membaca, mencatat, mengumpulkan data serta mengolah bahan penelitian yang bersumber dari jurnal, buku, artikel, serta internet. Dapat ditarik kesimpulan bahwa kuliah daring memiliki dampak terhadap kemampuan mahasiswa baik menurun ataupun meningkat yang kembali pada bagaimana pola belajar yang diterapkan pada masing-masing pribadi.
\end{abstract}

Kata Kunci : covid-19, kuliah daring, kemampuan mahasiswa

\section{A. Pendahuluan}

Saat ini negara-negara di dunia sedang dilanda oleh pandemi covid-19 termasuk negara Indonesia. "Pada akhir tahun 2019 merupakan tahun penuh kejutan bagi semua negara dibelahandunia. Hal ini disebabkan menyebarnya wabah penyakit bernama
Covid-19 yang mulai berkembang di Wuhan, Cina. Worrld Health Organization (WHO) menyatakan wabah penyebaran virus ini sebagai pandemi dunia saat ini. Hal ini juga dialamidi Negara Indonesia pada tanggal 2 Maret 2020 untuk pertama kalinya pemerintah mengumumkan dua kasus 
pasien yang dinyatakan positif Covid-19" (Jamil, S. H., \& Aprilisanda, I. D. 2020), dari pernyataan tesebut sejak diumumkannya kasus pertama di Indonesia pada bulan Maret lalu, Indonesia ditetapkan sebagai salah satu negara yang terpapar oleh virus korona atau covid-19. Saat Indonesia ditetapkan sebagai negara yang terpapar covid-19, kegiatan yang bersifat mengumpulkan kerumunan terpaksa dihentikan untuk sementara waktu hingga waktu yang belum diketahui, dan kegiatan yang dilakukan secara tatap muka atau offline dihentikan ataupun diistirahatkan untuk sementara waktu termasuk kegiatan dalam dunia pendidikan. Selain dengan kebijakan dihentikannya kegiatan yang bersifat mengumpulkan kerumunan pemerintah juga membuat sebuah kebijakan yaitu Pembatasan Sosial Berskala Besar (PSBB) yang diberlakukan dimasingmasing daerah sesuai dengan kebijakan yang diambil oleh masing-masing kepala daerah . Pemerintah membuat kebijakan ini tentu dengan berbagai pertimbangan guna mengurangi penyebaran covid-19 di Indonesia.

"Pendidikan adalah segala pengalaman belajar yang berlangsung dalam segala lingkungan dan sepanjang hidup. Pendidikan adalah segala situasi hidup yang mempengaruhi pertumbuhan individu" (Mudyahharjo, 2001:3) dari defisini tersebut terpampang jelas bahwa pendidikan sangat penting bagi kehidupan, hal ini mengapa siswa dan mahasiswa harus terus melaksakan pendidikan walau dalam keadaan apapun termasuk pandemi seperti sekarang ini, siswa terutama para mahasiswa harus tetap melaksanakan pembelajaran yang dilakukan secara online atau daring meskipun tidak dilakukan tatap muka secara langsung.

Kuliah daring merupakan sebuah sistem perkuliahan yang medianya memanfaatkan akses internet sebagai sarana untuk melaksanakan pembelajaran. Sistem perkuliahan daring tidak hanya di berlakukan di negara Indonesia saja namun banyak diberlakukan di negara lain, hal ini dilakukan demi mengurangi penyebaran virus korona yang sekarang sedang dialami hampir oleh seluruh negara di dunia.

\section{B. Metode}

Metode yang digunakan adalah metode studi literatur. Studi literatur merupakan kegitan dengan mencari referensi yang berhubungan dengan metode membaca, mencatat, pengumpulan data, dan mengolah bahan penelitian yang bersumber dari jurnal, review jurnal, buku-buku, artikel serta internet. Metode studi literatur digunakan untuk mencari dan mengumpulkan data penelitian dari sumber data primer yaitu dari hasil sebuah observasi, dan dari sumber data sekundar yang didapatkan dari dokumen jurnal, artikel dan internet. Dari metode studi literatur ini memiliki hasil akhir, yaitu mengentahui dampak kuliah daring terhadap kemampuan mahasiswa.

\section{Hasil dan Pembahasan}

Kuliah daring merupakan sistem yang diterapkan di dalam pelaksanaan pendidikan di tingkat universitas, yaitu sistem yang digunakan oleh para pengajar dan mahasiswa. Sistem perkuliahan secara daring ini diberlakukan guna mengurangi penyebarang 
covid-19 yang ada di Indonesia karena dengan diberlakukannya kuliah daring ini membuat mahasiswa dan para pengajar serta staf di perguruan tinggi tidak perlu melakukan kegiatan perkuliahan secara tatap muka demi menghindari kontak fisik guna mengurangi penyebaran covid-19 yang sedang melanda dunia terutama di negara Indonesia.

"Pembelajaran daring adalah pembelajaran yang memanfaatkan teknologi sebagai media perantara pengajar dan peserta ajar yang dapat dilakukan dengan tidak bertatap muka langsung antara pengajar dan peserta ajar tersebut yang biasanya menggunakan media komputer atau gadget yang berbasis pada jaringan internet yang artinya memilik karakteristik fleksibel dan mudah dilakukan oleh siapa saja, dimana saja dan kapan saja" (Thorne, 2003). Dalam pelaksanaan kuliah daring menggunakan sebuah media dengan memanfaatkan akses internet di dalam pelaksanaannya. Media yang digunakan dalam perkuliahan daring ini ada berbagai macam jenisnya, ada yang dalam bentuk e-learning dan ada juga yang dalam bentuk aplikasi untuk bertatap muka secara online, misalnya seperti zoom, google meet dan media lainnya, tentu media-media ini sangat membantu dan menunjang di dalam pelaksaan kuliah daring, dalam hal ini tentu ada saja kendela yang terjadi saat pelaksanaan proses pembelajaran secara daring seperti pernyataan di dalam buku "Menulis di Kala Badai Covid19" yang berkata "Bukan soal jaringan saja yang mengendala, keperlukan kuota menjadikan pengeluaran membengkak." (Abbas, E. W., \& Erlyani, N. 2020) pernyataan tersebut sangat banar, terutama bagi mahasiswa yang berada di wilayah yang jaringan internetnya kurang memadai yang kemudian mengahambat di dalam proses pembelajaran yang membuat mahasiswa dapat tertinngal materi yang dijelaskan oleh pengajar atau dosen, dan juga mahasiswa kendala ini terjadi pada mahasiswa yang memiliki keterbatasan ekonomi dimana mahasiswa tersebut memiliki kesulitan dalam membeli kuota internet karena terbatasnya keadaan ekonomi sehingga menyulitkan dalam membeli kuota. Masalah yang menghambat terlaksananya efektivitas pembelajaran dengan metode daring diantaranya adalah keterbatasan penguasaan teknologi informasi oleh pengajar dan mahasiswa, kondisi pengajar di Indonesia tidak seluruhnya paham penggunaan cara teknologi, hal ini dapat dilihat dari pengajar-pengajar yang lahir tahun sebelum 1980-an. Kendala teknologi informasi membatasi mereka dalam menggunakan media daring. Begitu juga dengan mahasiswa yang kondisinya hampir sama dengan pengajar yang dimaksud dengan pemahaman penggunaan teknologi, sarana dan prasarana yang kurang memadai perangkat pendukung teknologi jelas mahal. Banyak di daerah Indonesia yang dimana seorang pengajar pun masih dalam kondisi ekonominya yang menghawatirkan. Kesejahteraan pengajar maupun mahasiswa yang membatasi mereka dari serba terbatas dalam menikmati sarana dan prasarana teknologi informasi yang sangat diperlukan dengan musibah Covid-19 ini, tidak semua lembaga pendidikan baik Sekolah dasar maupun perguruan tinggi dapat menikmati internet. Jika ada pun jaringan internet kondisinya masih belum mampu mengkover 
media daring, dan kurang siapnya penyediaan anggaran biaya juga sesuatu yang menghambat karena, aspek kesejahteraan guru dan murid masih jauh dari harapan. Ketika mereka menggunakan kuota internet untuk memenuhi kebutuhan media daring, maka jelas mereka tidak sanggup membayarnya. Ada dilema dalam pemanfaatan media daring, ketika menteri pendidikan memberikan semangat produktivitas harus melaju, namun disisi lain kecakapan dan kemampuan finansial guru dan siswa belum melaju ke arah yang sama. Negara pun belum hadir secara menyeluruh dalam memfasilitasi kebutuhan biaya" (Aji, R. H. S. (2020).

Rata-rata mahasiswa yang saat ini hanya sedang membahas mengenai teori dalam perkuliahan mereka menggunakan sistem perkuliahan daring, yang sebagian besar dialami oleh mahasiswa baru atau yang biasa di sebut dengan maba, berbeda dengan mahasiswa yang dalam perkuliahannya selain membahas mengenai teori juga mengadakan praktik, sebagian besar terpaksa turun ke kampus untuk melaksanakan praktik karena tidak memungkinkan untuk dilaksakan secara online, biasanya ini dialami oleh mahasiswa semester tinggi atau mahasiswa semester atas namun tidak semua mahasiswa semester atas yang dalam pelaksanaan praktinya dilakukan secara offline atau turun ke kampus dan dilaksanakan secara online dirumah masing-masing. Dalam pelaksanaan praktik tidak hanya dialami oleh mahasiswa semester atas saja, namun mahasiswa semester awal pun sudah ada yang melaksanakan praktik secara offline, dan terpaksa datang ke kampus untuk melaksanakan praktik, tetapi mahsiswamahasiswa yang turun ke kampus untuk melaksanakan praktik tetap menerapkan dan mengikuti protokol kesehaan sesuai dengan peraturan pemerintah.

Saat pandemi covid-19 sekarang, mahasiswa terpaksa melaksanakan perkuliahan secara online atau daring yang dalam pelaksanaannya tentu memiliki berbagai dampak baik dari sisi positif dan sisi negatifnya. Dari sisi positif kuliah daring memberikan lebih banyak waktu dirumah untuk berkumpul bersama keluarga, bersama ayah, ibu, sodara, yang membuat mahasiswa lebih dekat dan lebih akrab bersama keluarag dirumah, dan dengan waktu luang tersebut mahasiswa dapat mengisi kegiatannya dengan berbagai hal seperti olahraga dan banyak hal lainnya yang dapat dilakukan untuk mengisi waktu luang. Dalam memanfaatkan waktu luang hal yang juga dapat dilakukan adalah menulis, seperti kalimat di dalam buku 'Menulis di Kala Badai Covid-19 “ berkata bahwa "Menulis menatap diri. Menulis memperbaiki diri yang karena itu menjadi mengasyikkan." (Abbas, E. W., \& Erlyani, N. 2020) yang artinya dapat memperbaiki diri dan mengisi waktu luang dengan menulis, karena menulis dapat menjadi sebuah kegiatan yang mengasyikan dimana pada saat pandemi seperti sekarang ini membuat seseorang menjadi lebih mudah jenuh dan bosen karena hanya berdiam diri dan hanya tinggal di dalam rumah. Kuliah daring juga membuat mahasiswa lebih mandiri dalam pembelajaran, disaat pandemi seperi sekarang ini mahasiswa di tuntut lebih aktif dalam menggali informasi mengenai materi 
yang diberikan oleh bapak ibu dosen yang tentu memudahkan dalam memahami materi, hal ini juga berguna dalam membentuk sebuah kemandirian pada diri mahasiswa di dalam proses pembelajaran yang berdampak pada kemampuan mahasiswa.

Disaat kuliah daring sekarang mahasiswa dituntut untuk tidak hanya mengandalkan penjelasan dari dosen saja namun harus menerapkan metode belajar mandiri, "Belajar mandiri diartikan sebagai kegiatan belajar aktif dengan dorongan motif untuk menguasai suatu kompetensi sehingga dapat menyelesaikan masalah serta belajar ini dibangun dari pengetahuan dan komptensi yang dimilikinya" (Mujiman, 2011). "Kemampuan untuk menyelesaikan tugas dan menentukan tujuan secara mandiri" (Trisiana, 2015). Kuliah daring memiliki berbagai dampak terhadap kemampuan mahasiswa, dampak yang terjadi pada kemampuan diri mahasiswa dapat berupa peningkatan atau bahkan penurunan, dalam dampak peningkatan dengan diterapkannya sistem perkuliahan daring membuat mahasiswa menjadi lebih mudah memahami dan mencerna dari materi yang dijelaskan dan bagi mahasiswa yang tidak menyukai proses pembelajaran secara bersamamaan dengan orang banyak menjadi lebih nyaman dan lebih mudah dalam memahami materi yang diberikan, dan juga membuat kemampuan mahasiswa lebih meningkat dalam memahami bagaimana penggunaan dan pemanfaatan media yang digunakan sebagai sarana pelaksanaan proses pembelajaran, namun kuliah daring juga membuat sebagian mahasiswa menjadi kesulitan dalam memahami materi yang diberikan oleh pengejar atau dosen hal ini karena mahasiswa lebih mudah memahami materi yang diberikan dengan sistem belajar offline atau dengan bertatap muka sacara langsung sehingga membuat mahasiswa lebih mudah dalam memahami materi yang disampaikan oleh dosen dan lebih mudah dalam berinteraksi dengan dosen secara langsung, namun dampak kuliah daring terhadap kemampuan mahasiswa kembali pada diri mahasiswa masing-masing, bagaimana pola belajar yang diterapkan pada diri sendiri yang kemudian berdampak terhadap kemampuan diri mahasiswa.

\section{Kesimpulan}

Pada masa sekarang dunia sedang dihadapkan dengan pandemi covid-19 termasuk negara Indonesia. Covid-19 merupakan virus yang menyebabkan terjadinya gangguan kesehatan hingga dapat berujung pada kematian. Sejak diumumkannya kasus pertama virus korona pada bulan Maret 2020 di Indonesia, maka negara Indonesia ditetapkan sebagai negara yang terpapar virus korona atau covid-19. Pandemi covid-19 di Indonesia membuat berbagai kegiatan terhenti tidak terkecuali dalam dunia pendidikan dimana proses pembelajaran terpaksa dilakukan secara online atau daring. Proses pembelajaran daring diterapkan disetiap jenjang pendidikan, mulai dari tingkat Paud hingga tingkat perguruan tinggi. Pada tingkat perguruan tinggi proses pembelajaran secara online atau kuliah daring dalam pelaksanaannya dilakukan menggunakan media dengan memanfaatkan akses internet 
sebagai sarana dalam pelaksanaannya. Di dalam pelaksanaan kuliah daring tidak bisa dihindari yang namanya sebuah kendala mengenai jaringan internet ataupun kuota. Kuliah daring membuat lebih banyak waktu berada dirumah untuk berkumpul bersama keluarga guna mempererat tali kekeluargaan. Kuliah daring memiliki berbagai dampak pada kemampuan mahasiswa yang membuat kemampuan siswa lebih meningkat atau bahkan menurun, mahasiswa yang lebih menyenangi metode belajar secara mandiri akan merasa lebih nyaman dan lebih mudah memahami dengan sistem belajar daring, namun kebalikannya mahasiswa yang lebih menyenangi sistem belajar dengan berkumpul bersama orang banyak dalam satu ruangan akan merasa kesulitan dalam proses belajar menggunakan sistem daring, dan mahasiswa yang terbiasa memahami seuah penjelasan materi secara langsung/offline akan merasa kesusahan dalam memahami suatu penjelasan. Metode yang digunakan adalah studi kajian literatur yang merupakan kegitan dengan mencari referensi yang berkaitan dengan metode membaca, mencatat, pengumpulan data, dan mengolah bahan penelitian yang bersumber dari jurnal, review jurnal, bukubuku, artikel serta internet yang digunakan untuk mencari dan mengumpulkan data penelitian dari sumber data primer yaitu dari hasil sebuah observasi, dan dari sumber data sekundar yang didapatkan dari dokumen jurnal, artikel dan internet. Dari metode studi literatur ini memiliki hasil akhir, yaitu mengentahui dampak kuliah daring terhadap kemampuan mahasiswa, dampak dalam kemampuan mahasiswa menjadi lebih meningkat atau bahkan menurun namun semuanya kembali kepada bagaimana pola belajar yang diterapkan mahasiswa dengan diri sendiri.

\section{E. Daftar Pustaka}

Abbas, E. W., \& Erlyani, N. (2020). Menulis di Kala Badai Covid-19.

Abbas, E. W. (2020). Menulis Artikel Jurnal Internasional.

Abbas, E. W. (2015). Unlam Menggapai Harapan. Wahana Jaya Abadi.

Aji, R. H. S. (2020). Dampak Covid-19 pada Pendidikan di Indonesia: Sekolah, Keterampilan, dan Proses Pembelajaran. Salam: Jurnal Sosial dan Budaya Syari.(7), 5, 395-402.

Aji, R. H. S. (2020). Dampak Covid-19 pada Pendidikan di Indonesia: Sekolah, Keterampilan, dan Proses Pembelajaran. Salam: Jurnal Sosial dan Budaya Syari.(7), 5, 395-402.

Amini, M., Mayangsari, M. D., \& Zwagery, R. V. (2020). Hubungan antara Kemandirian Belajar dengan Komitmen Tugas pada Mahasiswa Program Studi Psikologi. Jurnal Kognisia: Jurnal Mahasiswa Psikologi Online, 2(2), 149152.

Anggeline, E. M., \& Novita, N. (2020). 
TERHADAP

PENGUNGKAPAN

INTELLECTUAL CAPITAL. Jurnal

Akuntansi Trisakti, 7(1), 55-74.

Aridarmaputri, G. S., Akbar, S. N., \& Yuniarrahmah, E. (2016). Pengaruh jejaring sosial terhadap kebutuhan afiliasi remaja di program Studi Psikologi Fakultas Kedokteran Universitas Lambung Mangkurat. Jurnal Ecopsy, 3(1).

Binti Maunah, M. P. I. (2009). Landasan pendidikan.

Febriana, S. K. T. (2016). Faktor-faktor yang mempengaruhi stres kerja. Jurnal Ecopsy, 1(1).

Hidayat, Y. (2020). DIMENSI JURNAL SOSIOLOGI.

Jamil, S. H., \& Aprilisanda, I. D. (2020). Pengaruh pembelajaran daring terhadap minat belajar mahasiswa pada masa pandemik covid-19. Behavioral Accounting Journal, 3(1), 37-46.

MADYA, P. D. A. D. D. PERBEDAAN TINGKAT KECENDERUNGAN PERILAKU ALTRUISME.

Mansyur, A. R. (2020). Dampak COVID-19 Terhadap Dinamika Pembelajaran Di Indonesia. Education and Learning Journal, 1(2), 113-123.

Mutiani, M. (2015). Model Pembelajaran Sosial: Strategi Pembelajaran Afektif
Pendidikan Ilmu Pengetahuan Sosial Pada Kelas Konstruktivis.

Nurhayati, N., Akbar, S. N., \& Mayangsari, M. D. (2016). Hubungan Perfeksionisme dengan Kesejahteraan Psikologis pada Siswa Akselerasi. Jurnal Ecopsy, 1(4).

Rachmah, D. N., Mayangsari, M. D., \& Akbar, S. N. (2015). Motivasi belajar sebagai mediator hubungan kecerdasan adversitas dan prokrastinasi akademik pada mahasiswa yang aktif berorganisasi. Jurnal Cakrawala Pendidikan, 34(2).

Rahayu, S. (2020). DETERMINAN PENERAPAN KONSERVATISME AKUNTANSI DENGAN LITIGATION RISK SEBAGAI VARIABEL MEDIASI (Studi Empiris Pada Perusahaan Manufaktur Yang Terdaftar Di Bursa Efek Indonesia Periode 2016-2018) (Doctoral dissertation, Universitas Negeri Semarang).

Regina, A., Istiqomah, E., \& Zwagery, R. V. (2020). HUBUNGAN STRATEGI COPING YANG BERFOKUS PADA EMOSI DENGAN BURNOUT BELAJAR PADA MAHASISWA PROGRAM STUDI KEPERAWATAN FAKULTAS KEDOKTERAN UNIVERSITAS LAMBUNG MANGKURAT BANJARBARU. Kognisia prodi Psikologi FK ULM, 2(2), 7-12.

Riadi, S., Normelani, E. N., Efendi, M., Safitri, I., \& Tsabita, G. F. I. (2020). Persepsi 
Mahasiswa Prodi S1 Geografi FISIP

ULM Terhadap Kuliah Online Di Masa

Pandemi Covid-19. PADARINGAN

(Jurnal Pendidikan Sosiologi

Antropologi), 2(2), 219-227.

Setiati, S., \& Azwar, M. K. (2020). COVID-19 and Indonesia. Acta Medica Indonesiana, 52(1), 84-89.

Tanjung, M. D. A. (2011). Penerapan model pembelajaran clis untuk meningkatkan kualitas pembelajaran dan hasil belajar IPA siswa kelas III SDN Pisangcandi II malang/Akbar Tanjung MDA. Penerapan model pembelajaran clis untuk meningkatkan kualitas pembelajaran dan hasil belajar IPA siswa kelas III SDN Pisangcandi II malang/Akbar Tanjung MDA.

Zulva, T. N. I. (2020). Covid-19 Dan Kecenderungan Psikosomatis. J. Chem. Inf. Model, 1-4. 